\title{
MENCIPTAKAN IKLIM KENYAMANAN BELAJAR DI DALAM KELUARGA
}

\author{
Oleh : \\ Intan Kusumawati \\ Universitas Cokroaminoto Yogyakarta
}

\begin{abstract}
Abstrak
Menghadapi era globalisasidewasa ini, tuntutan pergaulan hidup amatlah besar. Sarana dan pra sarana pendidikanpun semakin maju. Namun sayang seiring dengan kemajuan teknologi yang serba vulgar maka tidak sedikit anak-anak usia sekolah yang salah menerapkan cara pandangan pergaulan dan pendidikan yang akhirnya menjadi salah pergaulan dan salah didik. Kemerosotan moral dan etika justru terjadi karena alasan kemajuan zaman dan teknologi terebut. Karena mudahnya akses pergaulan dan teknologi, maka tuntutan dunia pendidikan pun akhirnya suka tidak suka harus mengikuti perkembangan tersebut. Namun karena tidak adanya kontrol dari orang dewasa maka sering anak-anak usia sekolah memanfaatkan kesempatan dalam kesempitan. Maraknya warnet yang menyediakan sarana dan fasilitas internet sebagai sarana pelengkap sumber ilmu pengetahuan, namun kesempatan di warnet inilah yang menjebak anakanak usia sekolah justru berlaku asusisila sehingga justru menjebak dan merugikan anak iu sendiri. Didasari oleh keprihatinan itu, maka konsep iklim yang nyaman bagi siswa untuk tetap belajar di rumah menjadi pilihan yang lebih tepat agar orangtua masih dapat mengontrol perilaku anaknya. Maka konsep lama dengan berdasarkan konsep agama yang menjadi semangat dalam menciptakan usaha kenyamanan dan keamanan belajar bagi putra-putri adalah konsep RUMAHKU SURGAKU, dimana konsep ini dapat kita terpakan sebagai sarana pendidikan informal dan non formal sebagai modal dasar pencapaian keberhasilan pendidikan formal.
\end{abstract}

Kata Kunci: Iklim Kenyamanan, Belajar, Keluarga

\section{Pendahuluan}

Berawal dari keprihatinan dan keresahan orang tua terhadap kemajuan dan perkembangan zaman dewasa ini banyak sekali konsekuensi yang harus dihadapi oleh orangtua itu sendiri. Namun ironisnya, tidak semua konsekuensi itu dapat dipenuhi oleh orangtua itu sendiri. Khususnya dalam kemajuan tekhnologi di era internet ini, banyak orang tua yang gagap akan tekhnologi itu. Realitanya ada orangtua yang paham tekhnologi, namun tidak sedikit orang tua yang tidak memahami akan kemajuan tekhnologi alias Gaptek istilah zaman sekarang.

Karena tuntutan era teknologi itu, akhirnya bagi orang tua yang tak mampu memfasilitasi anak-anaknya untuk kepentingan itu mau tidak mau harus mengijinkan anak- 
anaknya mencari fasilitas di luar rumah. Walhasil, warnet menjadi incaran para pelajar yang di rumahnya tidak cukup fasilias.

Dengan kondisi semacam ini banyak anak-anak yang tidak bertanggung jawab akhirnya memanfaatkan keempatan dalam kesempitan. Akhirnya warnet sebagai tempat untuk janjian dengan kawan-kawannya. Tidak sedikit pula yang akhirnya memanfaatkan kesempatan itu untuk kencan dengan teman dekatnya. Berawal dari membuka materi-materi penunjang pendidikan dengan browssing dan berburu materi yang memang menunjang mata pelajaran yang sedang dia bahas, akhirnya muncul ide iseng untuk membuka situs-situs dewasa yang tidak selayaknya mereka konsumsi dalam usia yang masih begitu muda. Berawal dari rasa penasaran, akhirnya menikmati dan berujung pada tindakan praktik asusila sebagaimana yang banyak kita dengar dan kita lihat di media massa. Mengingat kondisi ini, maka orangtua hendaknya segera mengambil langkah-langkah antisipasi misalnya denga mengontrol anaknya ketika menyelesaikan tugas belajarnya di luar rumah. Langkah yang lebih tepat lagi fasilitasi anak dengan media belajar sesuai dengan kemampuan orangtua menurut skala prioritas. Dan utamanya adalah ciptakan iklim dan suasana nyaman dalam keluarga agar anak lebih memilih belajar di rumah ketimbang harus belajar dengan konsekuensi meninggalkan rumah. Ciptakan anak-anak yang bertanggung jawab mengatasi dan menyelesaikan tugas-tugas pendidikannya tanpa harus merugikan diri sendiri, teman dan orangtua melalui tindakan-tindakan yang tidak seharusnya dilakukan. Dengan menciptakan iklim yang aman, nyaman dan kondusif untuk belajar, maka anak pun akan merasakan rumahnya adalah sebagai surganya, sehingga dia tidak akan terbersit untuk mencari suasana dan fasilitas di luar rumahnya. Hal itu disebabkan karena anak-anak telah menemukan RUMAHKU SURGAKU.

\section{Adakah Rumah Di Surga Kita?}

Surga yang tergambar di dalam rumah kita bukanlah bermakna tekstual sebagaimana redaksi surga yang kita bayangkan melainkan lebih bermakna sebagai kiasan. Jika suasana di dalam keluarga itu aman, nyaman, tenang, tentram dan damai, maka hal ini menyebankan suasana yang kondusif bagi anak untuk betah tinggal di rumahnya. Dengan kondisi rumah dan keluarga sebagaimana di atas, maka akan menjadi tempat yang aman untuk tinggal, nyaman untuk belajar dan tentram untuk menjalin hubungan emosional antar anggota keluarga. Singkat 
kata, kondisi semacam itu akan menjadikan suasana yang positif untuk melakukan banyak hal. Namun persoalannya untuk menciptakan hal yang demikian itu bukanlah hal yang mudah, karena masing-masing anggota keluarga tentunya mempunyai kebutuhan yang berbeda-beda, sekaligus mempunyai suasana psikologis yang berbeda pula. Akhirnya untuk menciptakan suasana seperti itu merupakan sebuah keniscayaan. Sebagai umat muslim, sebetulnya telah banyak arahan dan pedoman yang dapat digunakan sebagai pegangan untuk menciptakan suasana semacam itu. Sumber pedoman dari Al Quran maupun Al Hadits dapatlah kita ambil sebagi petunjuk untuk menciptakan Rumahk Surgaku sebagaimana dambaan setiap keluarga.

\section{Agar Tercipta Surga di Rumah Kita}

Seperti kita ketahui, bahwa di dalam ikatan keluarga adalah terdiri dari berbagai unsur atau anggota keluarga yang di dalamnya bagaikan sebuah bahtera yang sedang mengarungi luasnya samudera. Dimana dalam bahtera itu terkandung orang-orang yang memiliki kedudukan dan peran masing-masing. Nahkoda adalah sang pemegang juru kemudi sekaligus penanggung jawab keselamatan bahtera dan seluruh isi beserta penumpangya agar selamat menuju pulau yang akan di singgahinya. Sebaliknya, seluruh awak kapal dan penumpang hendaknya menempatkan dirinya masing-masing sesuai dengan kedudukannya. Agar tercipta iklim yang nyaman di dalam keluarga, maka sosok ayah sebagai kepala keluarga adalah juru kemudi dan penanggung jawab laju dan keselamatan rumah tangga yang terdiri dari istri sebagai gambaran awak kapal dan anakanak sebagai penumpangnya. Jika masing-masing anggota keluarga telah menyadari dan akhirnya mampu menmpatkan diri sesuai dengan fungsi dan peran masing-masing niscaya akan tercipta sebuah keluarga yang harmonis.

Allah SWT telah mengingatkan tentang dasar penciptaan manusia dan mengatur peran serta fungsi masing-masing anggota keluarga tersebut agar tercipta sebuah keluarga yang sakinah, mawaddah warohmah. Perhatikan firman Allah dalam QS An Nisa ; 1 di bawah ini : 


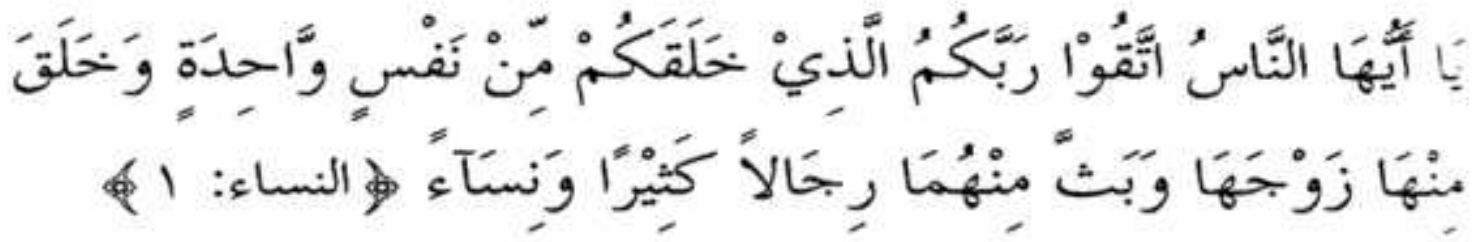

Hai sekalian manusia, bertakwalah kepada Tuhanmu yang telah: menciptakan kamu dari seorang diri, daripadanya Allah menciptakan: istrinya, dan daripada keduanya Allah memperkembangbiakkan laki-laki dan perempuan yang banyak. (QS. 4, al-Nisa': 1)

Berdasarkan ayat di atas marilah kita mencoba memahami kedudukan, peran dan funsi masing-masing anggota dalam keluarga itu. Ayah adalah nahkoda yang bertanggung jawab memgang kemudi rumah tangga. Ibu (istri) adalah sebagai asisten nahkoda yang berperan menasihati, mengingatkan dan mengontrol ayah (nahkoda) dalam mengemudikan laju rumah tangganya. Sedangkan anak bisa jadi sebagai penumpang yang harus dilayani, dijaga dan diantar menuju tempat yang ia harapkan. Jika semua komponan telah menjalankan tugas dan fungsinya dengan baik, maka perjalanan bahtera keluarga akan stabil. Jika semua kondisi stabil maka keluarga itu akan memperoleh kenyamanan. Jika sudah nyaman keadaannya, maka para penumpang akan merasa tenang tanpa rasa was-was sedikitpun tentang apapun. Mungkin di dapat membaca sesuatu di atas bahtera itu, melakukan aktifitas lain yang dapat di lakukan untuk memenuhi kebutuhannya, dan lain-lain yang dapat menambah kenyamanan selama dia tinggal bersama keluarga itu. Gambaran membaca dengan tenang inilah merupakan cerminan kondisi pembelajaran anak di dalam rumahnya. Untuk menciptakan hal yang demikian itu hendaklah diingat beberapa pesan penting di Tuhan berikut ini :

1. Membangun ruma tangga hendaknya didasarkan pada ketakwaan.Karena tidak akan mungkin keluarga itu mendapatkan kebahagiaan, kecuali dibangun dengan fundamen ketakwaan.

2. Allah menciptakan kita dan pasangannya adalah bermula dari diri yang satu. Artinya suami dan istri merupakan satu kesatuan yang utuh, yang disebut keluarga. Jika salah satu diantara anggota keluarga itu ada yang rusak akhlaknya, maka sesungguhnya keluarga itu sudah cedera. 
3. Istri adalah karunia Allah. Artinya istri yang mendampingi kita sekarang ini,bukan karena dijodohkan oleh orang atau teman, tapi Allah yang mngirim untuk menjadi jodoh kita.Oleh karena itu apapun kondisinya harus ridla menerimanya, agar Allah juga ridla kepada kita.

4. Anak-anak adalah karena karunia Allah, bukan karena kita pasangan yang subur. Jadi mereka adalah amanah Allah yang harus kita urus dengan segenap perhatian, tanggung jawab, perlindungan dan pengorbanan. Mereka harus di jaga dari ancaman api neraka dan harus dijadikan anak yang sholeh.

5. Perhatikan fasilitas dan pendidikan mereka agar meraka kelak menjadi manusia yang sukses baik dalam kehidupan di dunia maupun kehidupan di akhirat.

Ingat pesan Allah di bawah ini :

“Wahai orang-orang yang beriman, jagalah dirimu dan keluargamu dari api neraka, yang bahan bakarnya tebuat dari batu dan manusia..............?

6. Awas perhatikan, tanamkan dalam diri kita bahwa Allah akan mempertanyakan tanggung jawab kita dalam memenuhi ibadah (pelayanan) kepada Allah melalui Tugas, peran dan fungsi kita pada keluarga.

Jika di dalam setiap keluarga dapat mewujudkan suasana dan iklim seperti di atas, maka sudah barang tentu rumah tangga yang ada dapat dibilang telah menciptakan suasana keluarga yang ideal atau dalam koridor islam dikatakan sebagai keluarga yang sakinah, mawadah, warohmah. Sakinah karena di dalamnya tercipta ketenangan, mawadah karena anggota keluarganya senantiasa membangun rasa cinta kasih, warohmah karena dengan terciptanya keluarga yang tenang dan penuh cinta, maka rahmatnya Allah akan diberikan kepada hamba-hamba yang telah menciptakan pembinaan keluarga sesuai dengan apa yang telah Allah tuntunkan.

\section{Problematika yang Menjadi Faktor Penghambat}

Seperti kita ketahui, problematika sebuah rumah tangga amatlah kompleks. Banyak sekali faktor yang mempengaruhi kondisi baik buruknya keluarga karena ketidak seimbangan hubungan faktor-faktor tersebut.Dalam hal ini, hubungan yang konkrit adalah hubungan kekrabatan yang tercipta akibat perkawinan sesorang. Setelah menjadi suami istri tentu mereka akan mengharap lahirnya anak-anak sebagai keturunan dan buah hati yang meneruskan 
perjuangan dan cita-cita orangtuanya. Inilah hubungan yang disebut dengan hubungan intern keluarga. Baik buruknya hubungan intern keluarga akan menentukan tingkat kesolidan hubungan masing-masing anggota keluarga. Hubungan Ayah - ibu - anak adalah faktor hubungan utama untuk menciptakan suasana tenang dan nyaman dalam rumah tangga tersebut. Persoalannya ada keluarga yang bisa menciptakan suasana hubungan yang harmonis, namun tidak sedikit pula keluarga yang hubungan internnya tidak komunikatif, tidak komunikatihf atau bahkan yang lebih berat lagi terjadi broken home.

Faktor hubungan dengan keluarga dari suami atau istri acapkali memberikan pengaruh yang positif maupun negatif bagi intern keluarga. Jika dalam keluarga suami atau istri tercipta sebuah suasana yang kondusif, maka tentunya akan menjadi spirit bagi intern keluarga, namun sebaliknya jika hubungan dengan keluarga suami atau istri terjadi hubungan yang tidak baik atau bahkan saling menjatuhkan, keluarga suami atau istri tidak dapat menjadi teladan bahkan sering pula menjadi profokator, maka dapat dipastikan ini bukan menjadi spirit melainkan malah menjadi faktor penghambat bagi intern keluarga. Hubungan intern keluarga dengan masyarakat juga berpengaruh besar tehadap kelangsungan sebuah rumah tangga. Jika sebuah keluarga hidup ditengah-tengah masyarakat yang tenang, terarah dan terdidik. Maka ini akan memberikan pengaruh positif bagi intern keluarga. Namun sebaliknya, jika sebuah keluarga itu hidup di tengan masyarakat yang heterogen atau bahkan cenderung menggambarkan masyarakat yan rendah kadar pendidikan dan moralnya, keras dan kasar watak masyarakatnya, maka sudah barang tentu akan mempengaruhi dan membentuk sebuah keluarga menjadi keluarga yang keras juga karena pengaruh lingkungannya. Jika ada masyarakat yang demikian ini maka boleh dikatakan akan menjadi faktor-faktor penghambat bagi terbentuknya keluarga / rumah tangga yang damai, tentram dan nyaman.

Dengan mengingat banyaknya faktor yang mempengaruhi tingkat keberhasilan sebuah keluarga untuk menjadi keluarga yang sakinah, mawadah warohmah, maka hendaknya kita harus dapat memilah mana-mana faktor yang positif dan negatif yang mempengaruhi keberhasilan sebuah keluarga. Setelah memilah hendaknya dapat memilih jalan mana yang ditempuh untuk menciptakan suasana yang baik bagi keluarga kita. Kita ambil hal-hal yang baik bagi keluarga kita, dan saring kemudian jauhi hal-hal yang akhirnya dapat merusak keadaan keluarga kecil 
kita. Dengan demikian, maka kita bisa menjauhi memperkecil faktor-faktor yang menjadi penghambat keharmonisan keluarga.

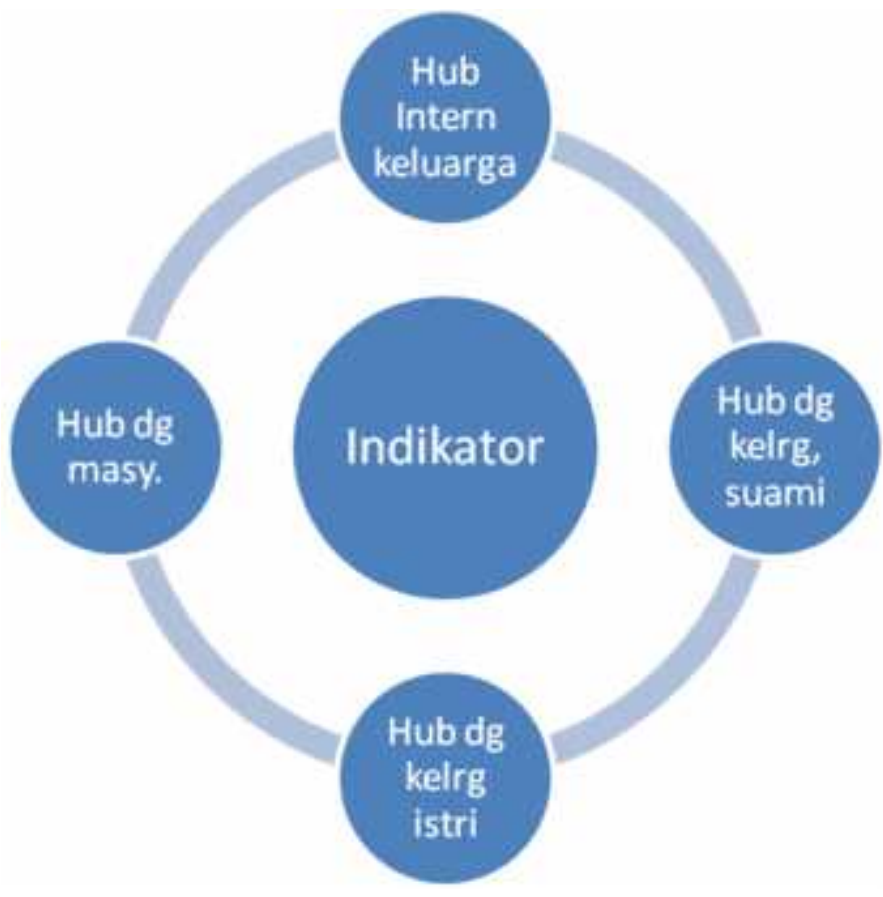

Itulah beberapa gambaran yang menjadi indikator keberhasilan sebuah rumah tangga dalam mencapai keharmonisan dan kesuksesan pendidikan keluarga tersebut. Selanjutnya sebuah keluarga itu harus pandai meraih indikator pendukung, dan menjauhi indikator penghambat agar tercipta keluarga yang sejahtera, terdidik secara intelektual sekaligus terdidik secara spiritual (agama). Oleh karena itu, bagi seorang muslim pedoman untuk menciptakan kebahagiaan rumah tangga adalah dengan niat untuk beribadah dengan dasar melaksanakan peintah Allah, menjalankan sunnah Rasulullah dan memilki tujuan untuk menciptakan keluarga yang sakinah, mawadah warohmah.

\section{Rumahku Madrasahku dan Masjidku}

\section{Langkah Awal}

Untuk mewujudkan agar suasana agamis dan gemar belajar di rumah sehingga tercipta kenyamanan di dalam keluarga, maka hendaknya rumah tersebut dikondisikan dengan gairah menimba ilmu dan semangat beribadah kepada Allah SWT. Dengan demikian maka akan terciptalah sebuah suasana nyaman, indah dan penuh harmonis di dalam rumah. Dengan suasana seperti inilah maka setiap anggota keluarga akan merasa betah jika berada di rumah. Dengan 
kenyamanan semacam inilah maka rumah akan tercipta sebagai madrasah (tempat pembelajaran) dalam segalah hal. Anak akan belajar berinteraksi dengan anggota keluarga yang lain, anak akan belajar pskologi, anak akan belajar berdemokrasi, anak akan belajar tentang ibadah, belajar, sholat, puasa dan doa sehari-hari bersama anggota keluarga yang lain. Dan tentunya masih banyak hal lain lagi di dapat diperoleh dan diaplikasikan di dalam rumah sebagai bekal kehidupan anak tersebut. Dengan menciptakan itu semua maka rumah akan menjadi madrasah sekaligus tempat ibadah bagi anak. Hal itu sejalan dengan perintah Allah sebagaimana firman Allah di bawah ini.

“...... Niscaya Allah akan meninggikan (derajat) orang-orang yang beriman diantaramu dan orang-orang yang diberi ilmu pengetahuan beberapa derajat. Dan Allah Maha Mengetahui apaapa yang kamu kerjakan. (QS. Al Mujadillah : 11)

Senada dengan itu, Rasulullah SAW juga telah menyampaiakan suatu pedoman bagi orang-orang yang gemar menuntut ilmu, tentu akan dimudahkan jalannya menuju surga berkat perjuangan dan beratnya seseorang berjuang menuntut ilmu. Berikut ini akan di cuplik sabda beliau sebagaimana tertera dalam hadits di bawah ini :

"Barang siapa meniti jalan untuk menuntut ilmu, maka Allah akan memudahkan jalan menuju surga." (HR. Muslim).

Dengan melihat nash di atas, maka dapatlah kita ketahui betapa tingginya Allah memberikan penghargaan kepada orang yang berilmu pengetahuan. Cerminan orang yang beriman tentu akan mengaktualisasikan imannya dengan banyak ibadah dimanapun ia berada, terlebih ibadah di rumah bersama dengan anggota keluarganya. Untuk itu Allah memberikan imbalan yang sangat besar yakni dengan anugerah surga sebagai pahalanya. Kepada orang yang berilmu pengetahuan Allah pun memberikan penghargaan yang besar karena Allah akan mempermudah jalan menuju surga, hal itu mengingat beratnya perjuangan orang menuntut ilmu sehingga dengan ilmu itu manusia menjadi tanggap untuk berbuat sesuatu kebaikan dengan ilmu yang diperolehnya itu. Untuk itu Allah akan ridla dengan orang-orang berilmu dan akan memberikan pahala besar bagi orang yang rajin belajar. Dengan iman, ilmu dan ibadah maka akan terciptalah kehidupan yang seimbang bagi pribadi seorang muslim. 


\section{Rumah Ideal Agar Tercipta Suasana Nyaman Belajar}

Setiap orang pasti meninginkan sebuah rumah yang ideal bagi seluruh penghuninya. Ideal untuk beribadah, berinteraksi dan belajar. Rumah yang kondusif seperti ini sangat di dambakan oleh siapapun juga. Di bawah ini akan di sajikan beberapa langkah yang sekiranya dapat dilakukan untuk membantu mewujudkan rumah ideal tersebut. Adapun cara dan sekaligus ciriciri rumah ideal adalah sebagai berikut :

1. Ciptakan rumah yang memiliki suasana haus menuntut ilmu. Tiada hari tanpa menambah ilmu. Nampaknya itu slogan yang patut kita realisasikan dalam kehidupan sehari-hari bagi seluruh enggota keluarga.

2. Seluruh anggotakeluarga harus dikondisikan gemar mencari ilmu. Karena dengan ilmu akidah dan ibadah akan menjadi lurus.

3. Hendaknya orangtua selalu mengingatkan kepada anak-anaknya agar selalu mengingat dan menysukuri anugerah besar yang telah Allah berikan pada mansia. Potensi besar yang telah Allah anugerahkan antara lain :

\section{Anugerah Jantung}

- Berdetak 100 ribu kali sehari

- Memompa 1.500 galon darah setiap harinya

- Pembuluh darah yang panjangnya $2 \times$ keliling bumi pada garis ekuatornya. 


\section{Anugerah Otot Pada Tubuh}

- Apabila semuanya bekerja bersama-sama, akan memiliki kekuatan daya tarlk setara dengan 25 ton.

\section{Anugerah Otak}

- Hanya membutuhkan daya listrik setara lampu 10 watt, tetapi kemampuannya setara komputer tercanggih yang disatukan dalam gedung bertingkat 100 .

- Memiliki 100 milyar sel aktif yang mampu membentuk 3 milyar koneksi/detik, lebih dari koneksi yang dibuat para pengguna internet di seluruh dunia dalam 3 hari.

Dengan semua potensi di atas maka sudah selayaknyalah andaikata manusia berfikir dan memikirkan tentang jati diririnya, kedudukannya dan apa saja yang harus di lakukan dan apa pula yang tidak harus dikerjakan. Karena sifat manusia yang lupa, dan kodrat manusia yang lalai. Maka seharusnyalah manusia mau belajar. Barang siapa gemar belajar dan mencari ilmu maka Allahpun akan menyayanginya. Allah akan ridla dan senantiasa membimbingnya dalam kebenaran, kebaikan dan kemanfaatan. 


\section{Jadikan Rumah Sebagai Sumber Ilmu}

Ada beberapa cara yang dapat ditempuh sebagai cara belajar dan menjadikan rumah tinggal kita menjadi sumber ilmu. Cara-cara tersebut antara lain :

1. Perbanyak koleksi buku yang bemanfaat untuk pengembangan pengetahuan keluarga, sehingga rumah serasa memiliki perpustakaan keluarga.

2. Membiasakan setiap anggota keluarga untuk belajar bersama, membahas dan mendiskusikan suatu ilmu pengetahuan sehingga serasa di dalam rumah itu memiliki laboratorium keluarga.

3. Sesekali di adakan "bedah buku" bersama anggota keluarga dengan cara salah satu anggota keluarga membaca sedangkan yang lain mendengarkan dan selanjutnya membahas bersama tentang isi buku tersebut.

4. Menyaksikan siaran televisi tentang kajian agama maupun ilmu pengetahuan umum, kasetkaset ceramah agama, VCD/DVD tentang ilmu agama maupun ilmu pengetahuan, siaran radio dan laian sebagainya.

Disamping sebagai tempat belajar sebagaimana di atas, rumah juga harus digunakan sebagai sarana untuk beribadah bersama keluarga. Laksanakan shalat berjamaah bersama istri dan anaak-anak dengan Qiyamul-lail, membaca al Quran, berdzikir bersama anggota keluarga adalah merupakan bentuk usaha penciptaan susasana religi di dalam keluarga. Dengan nuansa religi yang demikian itu maka akan tercipta sebuah rumah yang bernuansa sebagai tempat ibadah. Hasil akhir yang di damba adalah terciptanya rasa syukur yang mendalam dalam setiap lubuk hati anggota keluarga atas sgala nikmat pemberian dari Allah SWT.

Ingatlah pesan Rasulullah “Baitiy Jannatiy”, artinya bahwa beliau merasakan rumah tangganya serasa di surga. Penuh dengan pengertian, damai, saling menyayangi, saling mempercayai, saling mengisi dan mengingatkan. Sehingga dalam rumah beliau tercermin dalam suasana akhlakul karimah. Cahaya ketakwaan selalu memancar dari rumah beliau, dimana cahaya itu muncul karena rumah tersebut sarat dengan ibadah kepada Allah SWT dan teraplikasi dalam kehidupan di tengah-tengah masyarakat sesama manusia. 


\section{Kesimpulan dan Hikmah}

Rumah tangga yang harmonis adalah rumah tangga yang mencerminkan ketentraman, kedamaian dan toleransi yang baik diantara anggota keluarga. Dengan kondidi seperti itulah maka akan didapatkan sebuah keluarga yang mencerminkan susasana nyaman untuk belajar, baik ilmu pengetahuan agama maupun ilmu pengetahuan umum. Sekaligus rumah tersebut dapat di jadikan laboratorium atau sarana tempat ibadah sebagai bentuk aplikasi illmu yang telah di pelajari.

Ada beberapa hal yang dapat di ambil sebagai langkah untuk mewujudkan suasana Baitiy Jannatiy sebagaimana telah di contohkan dalam rumah tangga Rasulullah SAW. Langkah tersebut adalah :

1. Selalu mementingkan introspeksi dan muhasabah terhadap segala kekurangan atau kesalahan. Raih ampunan Allah sesegera mungkin sebagai bentuk pertaubatan dan penghambaan kepada Allah SWT.

2. Menafkahkan harta di jalan Allah demi kemanfaatan baik dalam keadaan lapang maupun sempit. Ini sebagai simbol bahwa kita harus memperhatikan kepentingan sesama manusia (Hablu minannaas) di awali dengan sikap empaty kepada sesama anggota keluarga dan meluas kepada manusia lain di sekitarnya.

3. Mampu menahan amarah dan mengendalikan diri dalam suasana apapun. Ini sebagai cerminan bahwa keluarga kita hidup selalu dalam koridor akhlakul karimah.

4. Mudah memaafkan kesalahan orang lain. Ini merupaka simbol akan kearifan kita terutama ketika menyangkut kesalahan diantara sesama anggota keluarga.

5. Selalu menjaga agar senantiasa berbuat baik pada sesama anggota keluarga.Ini merupakan simbol bahwa setiap anggota keluarga senantiasa gemar berbuat baik kepada sesama manusia yang lain. Dan tanamkan pada setiap jiwa anggota keluarga "Bahwa Allah menyukai orang-orang yang suka berbuat kebaikan." 


\section{Sebuah Hikmah}

Pernah diriwayatkan, bahwa pada suatu ketika Allah berdialog dengan Musa AS. Ketika itu Musa sedang bermunajat kepada Allah SWT, tiba-tiba Allah bertanya kepada Musa :

Allah : "Wahai Musa, sungguh telah banyak ibadah yang telah kamu lakukan, namun sayang semua ibadahmu itu hanya untukmu. Mana ibadahmu untuk Aku ?"

Musa : "Ya Allah, semua ibadahku hanya untukmu. Shalatku, puasaku, zakatku dan dzikirku semuanya hanya untuk-Mu."

Allah : "Belum.... Semua ibadah yang kamu lakukan itu masih untukmu”.

Musa : "Kalau begitu, tolong beritahukan kepadaku, apa yang ibadah untuk-Mu itu."

Allah : : "Berkhidmatlah kepada hamba Ku yang lain."

Makna dari berkhidmat kepada sesama manusia itu adalah memperhatikan, membantu dan melayani hamba Allah yang lain dengan sepenuh hati tanpa mengharapkan balasan dari sesama, melainkan hanya mengharap ridla Allah SWT. Semoga tulisan ini dapat memberikan kontribusi terhadap pemahaman tentang pentingnya keseimbangan ilmu agama dan ilmu pengetahuan agar pengamalan di dalam kehidupan sehari-hari tidak menyimpang dari kehendak dan perintah Allah SWT.

\section{Daftar Pustaka}

Al Hikmah, Al Quran dan Terjemahnya, Departemen Agama RI, Yayasan Penyelenggara Penterjemah Al Quran, Disempurnakan oleh Lajnah Pentashih Mushaf Al Quran, CV Diponegoro, Semarang, 2005.

Muntakhab Ahadits, Syaikh Maulana Muhammad Yusuf al-Kandahlawi, Ash-Shaff, Yogyakarta, 2007.

Ringkasan Ihya Ulumiddin, Imam Al Ghazali, Gita Media Press, Surabaya, 2003.

Sosiologi, Suatu Pengantar, Soerjono Soekanto, PT Raja Grafindo Persada, Jakarta, 2006.

Kumpulan Hadits Terpilih Shahih Bukhori, Ust. Maftuh Ahnan Asy, Terbit Terang, Surabaya, 2003. 